\title{
ISLAM AND TRADITION IN NANGA JAJANG: SOCIAL AND RELIGIOUS PRACTICES OF THE MALAY COMMUNITY
}

\author{
Ibrahim MS \\ Pontianak State Institute of Islamic Studies
}

\begin{abstract}
Islam basically brings noble values in managing human relationship with God (hablumminallah). With these noble values, Islam teaches the way for humans to worship God. Meanwhile, traditions which are the rituals and customs of a society, is also an attempt to build a relationship with something other than human. Therefore, it is clear that Islam and traditions that are present in people's behavior also bring certain values that are different from each other. In the Malay community of Nanga Jajang, Islam as a religion and religious rituals are inseparable from the traditional rituals. In fact, there are no clear boundaries between traditions and religious rituals in practice, as seen in ma'syiral jum 'atan, acara begunting rambut (hair cutting ceremony), sunatan (circumcision), barobat kampung (traditional healing), etc. In social traditions, religion practices also run simultaneously such as reading the Qur'an and shalawat to the prophet. On the other hand, religious practices are also incorporated into elements of local traditions such as the hair cutting ceremony for infants, circumcision, etc., with a set of materials that are also found in social traditions. Similarly, the prayer used in the traditional healing appears to have the process of completion, even accommodation of Islamic values and traditions in the practice of the life the Malay community in Nanga Jajang.
\end{abstract}

Keywords: Islam, traditions, religious rituals, accommodation of values.

\section{INTRODUCTION}

This article is an introduction to the study of Islam and Tradition in Nanga Jajang. As an introductory study, this article still requires more serious efforts in analytical work to make it better, and therefore it is also very open to be explored and developed further. Nonetheless, I hope that this basic research will initiate passion to conduct a more in-depth, real and comprehensive study, especially for me, myself. As a field study, this work was based on the phenomenon that I observed over the years, especially with regard to social and religious traditions of the Malay community in Nanga Jajang which are very complex but quite open. Being complex here means that there are various forms of social and religious traditions that live and thrive in the community, 
in this case, particularly the combination of the values of the local culture and religion that can be seen clearly. Being open means that there is never a real problem to the differences that arise in the community, including differences in the cultural and religious practices in society.

In contrast, the presence of Muslim communities in the interior of the Kapuas has an important value of its own in this study, especially regarding the theses proposed by many experts that identified the spread of Islam (the Muslim community) only in coastal areas. Deep in the interior of the Kapuas, there is a Muslim community characterized by social and cultural characteristics. They go through life with very different characteristics in the form of a mix of values of local social culture with religious norms (read: Islam). The blend of values of life is what is interesting to study, in this case, that I refer to as the study of Islam and tradition.

For me, the social and religious life of the Malay community in Nanga Jajang which is complex and open, not only is it an interesting subject to study, but it is also interesting to understand and learn the social and religious traditions of the community itself (in this case the Malay of Nanga Jajang). With all the limitations of data and depth of study, this article seeks to address some of the Islamic values and traditions practiced by the Malay community in Nanga Jajang, including ma'syiral tradition on Friday, the tradition of plain flour, traditional circumcision, baby hair cutting, prayer, etc. To see the values of Islam in the whole tradition, this paper discusses in more detail the analysis of prayer recital in the Malay community of Nanga Jajang.

\section{NANGA JAJANG AS A MUSLIM VILLAGE}

Nanga Jajang, is a small village at the hamlet level, located in the interior of Kapuas Hulu, West Kalimantan. The village is located just off the coast of Lintas Selatan Road which connects the city of Pontianak to Putussibau. The distance of the village of Nanga Jajang to Pontianak city is about $650 \mathrm{~km}$, while to Putussibau city is approximately $100 \mathrm{~km}$. With the ease of current transportation, it is not too difficult to visit this village, because it is situated on the main road that connects Pontianak to Putussibau.

The name of this village, Nanga Jajang, is closely related to the traditions and customs of the people of Kapuas Hulu in particular, and West Kalimantan in general who prefer to name a place after the river or estuaries. Nanga in the local Malay language means estuary of a river. So, Nanga Jajang is the estuary where of the Jajang River (see in Ibrahim, Yusriadi \& Zaenudin, 2009).

Nanga Jajang village lies along the the shape of the Jajang River and Pengkadan 
River, which is where the estuary of the rivers is located. However, at this time, the residential area tends to follow the path of Lintas Selatan Road. The change in settlement pattern like this is very common in Kapuas Hulu, especially in a village which is situated by the highway. The old village is even almost abandoned, because people prefer to build a new settlement on the coastal highway (a new village). As a small village at the hamlet level, Nanga Jajang is inhabited by the majority of Malays with approximately 345 residents.

\section{ISLAM IN NANGA JAJANG}

As the followers of Islam in the archipelago in general, the Malay in the interior of the province are adherents of Ahlussunnah waljamaah (Sunni) in theology, and followers of Syafi' $i$ in fiqh (see study Hermansyah, 2008). Similarly, the Malays in Nanga Jajang, are Sunni Muslims and followers of Syafi i school of thought. This is evident in their religious practices of Islam which refers to a religious belief which makes the Sunnah or the habits of life of the Prophet as the legal basis and guidelines for religious life, in addition to the direct provision of the Qur'an. In the socio-religious organization in Indonesia, Sunni Islam is a religious spirit developed by Nahdlatul Ulama (NU). The religious ideology is also often referred to as traditional Islam (Barthon, 1999).

As followers of Sunni Islam, Ahlussunnah becomes the characteristics of the religious practices of the community in Nanga Jajang. This is shown in the religious behavior of the community, including the patterns of thinking, behaving and worship. In thinking and behaving, for example, the Muslim community in Nanga Jajang believe that the Sunnah (the good habits practiced by the Prophet) becomes a solid legal basis and should be followed in religion. Likewise in the case of worship, the usual ways exemplified by the Prophet (Sunnah) are the main guidelines in performing religious teachings as can be seen from the way people perform religious rituals such as Friday prayer still using ma 'asyiral, tahlilan in death ritual, hair cutting accompanied by sacred procedures, Barzanji, etc.

Several forms of the religious practices characterize the close relationship between religion (the command of syara') and the religious traditions in the community at Nanga Jajang. In general, such religious characteristics which become the traditional Islamic religious identity (Sunni), in Indonesia has always been seen vis a vis with the modern Islamic religious rituals (Muhammadiyah).

The characteristics of Sunni Islam practiced by the community of Nanga Jajang can be observed in their religious activities. Therefore it is easy to find 
some of the typical religious rituals performed by the Sunni community of Nanga Jajang such as ma 'syiral and adhan (call for prayer) that is delivered twice prior to Friday prayer, tahlilan as part of the death ritual, practice of reciting the Barzanji and sacred procession in the hair cutting ceremony, etc. Such traditions would not be found in the Muslim community who follow modern Islamic school of thought (Muhammadiyah), although in many cases, the differences in ideology of traditional Islam and modern Islam from the viewpoint of the amaliah could no longer be used for labeling a society as Sunni or Muhammadiyah² (see Ibrahim, 2013).

In the case of Nanga Jajang, at least such characteristics of Islamic religion (traditional) are still significant to give them the religious identity of Sunni Muslims because such religious practices allow for the existence of social traditions of behavior and religious life in Nanga Jajang.

\section{TRADITION IN THE NANGA JAJANG COMMUNITY}

In this section we will discuss the social traditions of the Nanga Jajang community. First of all, we must of course be able to sort out between the religious rituals and traditions, because religion is different from tradition. Similarly, tradition is not religion itself. As a matter of fact, it is not easy to give a clear boundary between the ritual traditions and religious rituals that have run for years in the history of the community life. However, we do not then simply generalize between the two. We must always strive seriously and consciously to see which are religious rituals (religious activities ordered by syara') and which are ritual traditions (social/cultural activities) of a society because, only with this can we guarantee the preservation of religious values so as not to mix with others.

Discussion of the traditions of society in Nanga Jajang means discussing some social activities done by the community for generations. In the context of this study, the tradition meant here is public rituals that accompany the implementation of religious orders such as Friday sermons, hair cutting, traditional healing, building houses, farming, abstinence, etc.

Friday prayer for example, with two raka'at and delivering a sermon, is actually a very clear command of Allah in the Qur'an (see Surah 62: 9), and several hadiths of the Prophet. However how that is done by the religious community

2 For example, the Taraweh prayer is communly done in 20 rakaat by those affiliated to Nahdlotul Ulama (NU), but those affiliated to Muhammadiyah do it in 8 rakaat only. Muslims in Nanga Jajang do it following the practice by Muhammadiyah but they are not necessary to belong to Muhammadiyah group.In fact NU traditions characterize the way the pople in Nanga Jajang practice their religion. 
to accompany the command is what I refer to as a tradition. One of them is ma 'asyiral. ${ }^{3}$ Based on several sources, including the hadith of the Prophet, ma 'asyiral was originally a tradition that was practiced by the Prophet, in the form of an introductory speech to the congregation to carry out obligations properly and attentively in Friday prayer. Moreover, even when the preacher would rise to the pulpit, he was also given an iron stick and a robe/scarf as a marker giving a mandate to deliver a sermon. The tradition (especially holding a stick) could heve been done by the Prophet with a particular purpose. However, with the current conditions, it seems that such practices are merely a tradition whose meaning is no longer known. However, the tradition is still maintained by the community. Even for the most part, they regard such practices as something that must be performed (required). If the procession is not done, then it is viewed as errors in worship (not allowed).

Cutting a baby's hair is also an explicit command by the Prophet through his hadith. But how to do it, that's what raises many differences in the practice among the people. As an example of reading Barzanji and syarakalan to accompany the practice has become a requirement in some communities, including that of Nanga Jajang even though Barzanji and syarakalan are a tradition that came later (after the Prophet died). Thus, the barzanji and syarakalan are not the only part of this ritual. Not to mention when viewed from a set of properties in the ceremony hair cutting which is filled with traditional practices of local communities. Son what value is understood by the Muslim community in practicing the tradition of hair cutting of their infant? There is a concern from those who practice these traditions as to find it difficult to distinguish between religious deeds and traditions. Their understanding of Sunni Islam indeed gives space to the flourishing of this tradition, because it is the preservation of the traditions of the Prophet. Therefore the chanting of praise and invocation to the Prophet become a key feature of the ritual tradition ${ }^{4}$, in addition to understanding the history of the struggle of the Prophet when spreading Islam.

It is also the case with the traditional healing. Islam simply instructs its followers not to be desperate of Allah's mercy and help, including in the case of illness. Even the Qur'an gives a guarantee that the disease is part of Allah's

3 The word Ma'asyiral is originaly to convey message from the Prophen Muhhamad to begin the Jumah prayer. And the Maasyiral is not an obligatory within the Jum"at prayer. But the people of Nanga Jajng seem to believe that Maasyiral should be done in the performing of Jumat prayer.

4 Where is the point of local tradition in the hair cut ritual? Among others is reciting Al-Barzanji. Shalawat is recited within the ritual of Barzanji performance. This is not eambaded to the ritual but is as a Sunnah by the Prophet Muhammad which needs to be practiced by Muslims. 
creation, and Allah also created a cure to heal it (Qur'an 26: 80). Therefore, man is told to ask (pray) to Him (Sura 2: 186). However, how is the practice of asking/praying for that? That is why people eventually invented traditional healing (plain flour/prayer/spell).

In Nanga Jajang, traditional healing is still an important option in the community. With the traditional healing, they believe that a cure will be found, and that's why there are two models of this tradition in the history of their life;

First, the traditional healing in the form of an intermediary prayers being said to Allah for healing the sick. In this model, it usually contains very simple ritual properties such as water or rubbing one's thumb or index finger on the forehead, abdomen or the affected part.

Second, traditional healing in the form of mediation of spells or specific chanting that is believed to provide healing. In this form, there are a lot of ritual properties, ranging from natural ingredients to objects that are hard to understand its relevance in the common sense (irrational). This tradition is also found in Nanga Jajang, although it has been somewhat uncommon due to the people's shifting belief in supernatural powers to modern medical methods (doctors and paramedics).

Other traditions that are still preserved by the Muslim society in Nanga Jajang are related to activities when they build houses, prepare land for farming and even in many forms of abstinence (see in Ibrahim, Yusriadi and Zaenudin, 2012). So the question is, is there a tradition they practice that violates the teachings of the religion? Or are there any religious values inherent in the social traditions of the community? This will be elaborated further in the following sections.

\section{ISLAMIC VALUES IN THE TRADITIONS OF THE COMMUNITY}

When talking about the Islamic values, first we need to understand some basic provisions of Islam as a religion, in this case the concept of monotheism. Tauhid in Islam understood as the Oneness of God in all His nature. With this Tauhid, Islam requires every community to realize and acknowledge that Allah as the only place of origin and return for humans. Therefore on Allah everything rely (QS 1: 5). Allah is where all the creatures shall return (Sura 2: 156), Master of the Judgment Day (QS 1: 4; Sura 67:1), because it is Allah who owns everything (Sura 34: 1). Tauhid is the basis of the teachings of Islam, because a person is recognized as Muslim when he/she pledges the tauhid (shahadah).

Meanwhile, the Malay in Nanga Jajang have a religious history like most 
Muslims in the interior of Borneo, whom King (1993) referred to as the nonMalays who later became Malay because of embracing Islam. Although not known for certain when this religious conversion occurred in Nanga Jajang, it is certain that this process did occur to the Malay community Nanga Jajang, because of the history of the spread of Islam to the interior of West Borneo. We also could not confirm the name of the community group in Jajang Nanga before becoming Malays and embracing Islam.

As a local community (before the coming of Islam), of course, there were many life habits practiced by the community at the time, and some may still be maintained for generations to generations of the Malays today. Some local traditions in the Malay community are still in existence due to several factors, as follows. First, when Islam entered carrying the values that accommodated between the teaching of Islam and local traditions, with the philosophy of "accepting the good of something new, and maintaining the good of something old". With such views, then when Islam came, it did not immediately remove all (good) traditions in the community. Islam came by utilizing (good) traditions to simplify the process of dakwa, as carried out by the Wali Songo who used the puppet tradition as a method of preaching the religion in Java (see Azra, 2002).

Secondly, Islam was accepted by the people of Indonesia rather a form of adhesion according to Nock (in Azra, 2002) who defined it as a process of acceptance of Islam as a religion without leaving the beliefs and practices of the old culture. Third, Islam came by slowly influencing the way of people's life for the better (more Islamic), as the prophetic meaning of Islam which requires adherence and commitment as the only way of salvation. Despite the fact, Islam came not by just giving orders and prohibition, but based on the understanding and awareness of the better (a gradual process). An example in this case is the magic tradition which is still very strong in the Malay community of Kapuas Hulu (see in Hermansyah, 2010).

In the context of the study of Islam and tradition in Nanga Jajang, I would like to provide an analysis of the accommodating values in such tradition of magic (prayers or spells). Here are some examples of spells in the science of magic, which reveal the process of Islamization or accommodation between the values of local tradition (pre-Islamic period) with the values of Islam (which came later), as can be seen in the following example of prayer/spell. 


\section{SNAKE SPELL}

Urat pusat mamang kunin

Raja mungkar dalam tanah

Menyengkung seperti akar

Berdiri seperti kayu

Mati yang kunin

Idup yang putih

Tabar bisa nait tawar

\section{Berkat doa la ila ha illlallah}

\section{Berkat muhammad rasulullah}

the navel's nerve is yellow

the cruel king is in the ground

holding on like roots

standing like a tree

Dead is the yellow

Alive is the white

poison is defeated by spell

Thanks to the prayer la ila ha illlallah

Thanks to muhammad rasulullah

Source: Hermansyah, 2010: 151.

The spell is read to treat someone who is bitten by a snake. The lines of the prayer show that the core is in the last verses (before the words, because of the prayer), namely "Tabar bias nait tawar" (poison is defeated by spell). It means that the poison of a snake bite will be gone, and the person bitten by the snake will survive. From the above examples it appears that the original lines of prayer were pure practice of tradition, and local language was used. Then the coming of Islam, the prayer was not necessarily discarded, but was still practiced by adding Islamic nuances to the lines, although in general the local language is still a feature of the prayer or spell. Apparently, it is an accommodation of local and Islamic values in the expression of because of the prayer la ilaa ha illallahu, because of Muhammad the Messenger of Allah.

Another example can be seen in the excerpt of the following prayer/spell:

Spell for the sick:

Bismillahirrahmanirrahim

Cuka apa cuka itu

Cuka ada dalam pasu

Luka apa luka itu

Luka pantap utan semolih Antu

Berkat doa la ila ha illallah

Berkat muhammad rasulullah 


\author{
Bismillahirrahmanirrahim \\ vinegar, what vinegar is it \\ vinegar is in a container \\ wound what wound is it \\ Stabbed wound of the forest slaughter ghost \\ Thanks to the prayer la ila ha illallah \\ Thanks to muhammad rasulullah
}

Source: Hermansyah, 2010: 154.

The spell is read to treat people with a sudden illness, because the belief of the Malays in Nanga Jajang that a sick person is caused by ghost interference. That's why it is called tekonak (meaning being disturbed by supernatural beings). Almost the same as the first example, where the four main lines in the prayer showed characteristics of long tradition in the community, and expressed in the local language. Then Islam gave better color to the tradition of the spell / prayer. That is evident from the opening words of prayer with Bismillahirrahmanirrahim, and ends with a prayer la ilaha illallah, Muhammad Rasulullah as a form of accommodating Islamic values and traditions. Compared with the first example, the second example is a clear accommodation of Islamic values in the tradition of the prayer / spell, and still practiced in the Malay community in Nanga Jajang. Below is another example of the spell that is still practiced by the Malays in Nanga Jajang, which has been more accommodating of Islamic values.

Pelias berjalan prayer

Allah payung ku

Jibril kota ku

Malaikat empat puluh empat pagar ku

Aku berjalan dengan kuasa Allah

Aku melenggang dengan lenggang Muhammad

Bukan kata ku, kata Allah

Berkat do`a la ilaha illallah

Berkat Muhammadurrasulullah

Allah is my umbrella

Gabriel is my city

Angel of my forty-four fences

I walk with the power of Allah

I stroll with the stroll of Muhammad

Not my word, the word of Allah

Thanks to la ilaha illallah

Thanks to Muhammadurrasulullah

Source: Ust. Saleh Kamaruddin (the late) 
From the example above, it seems that Islam values (the terms in Islam) have influenced most of the lines of the prayer / spell. Even as a whole (in the form of sentences), the prayer already illustrates the values of monotheism in religion. While local values, in this case the local language, is no longer visible, due to a change or influence of the language of education (Indonesian language). For sure, these changes become one of the refinement of Islam against the traditional values of society, that is accommodating in its nature. In addition, the accommodation of values in the tradition of the Malay community of Nanga Jajang can also be seen in the form of lyric poetry as shown in the following bargaining topung tawar ${ }^{5}$ do `a.

\section{Topung Tawar Prayer}

topung tawar si topung jati,

topung asal mula menjadi,

amay-amay pucuk mali-mali

limau purut si limau lelang

tegak dengan limau melaka

air surut penyakit ilang

tegak dengan sial celaka

Sumber: Uju Unui (alm), Interviewed in November 2009

The lines of the prayer are recited by a traditional leader on fresh flour water before it is splashed to someone being prayed for. Regarding the matter of splashing water to those who are treated, according to him, may be done three, five or seven times. However most people choose to do it three times only. After splashing the water of fresh flour, the ritual of sowing yellow rice to the person who is prayed for, by reading the following prayer.

Kuu.. semongat rezeki murah

apa dicinta lalu ada

apa diniat lalu didapat

manis muka senang hati

Kuu .. semongat easy sustenance

What desired, then it comes to existence

What wished, then it is obtained

sweet face joyful heart

Source: Uju Unui (alm), Interviewed in November 2009

5 Tepung Tawar or Topung Tawar in local dialec is a ritual of prayer accompagnied by local tradition ceremonials to support many different event including wedding, circumsition ang other traditional rituals. See Ibrahim (2010) and compare to Erwin and Andi Gidang (2010) for more details. 
The lines of this prayer are usually recited while sowing yellow rice to a person who is prayed for. This tradition is performed by putting some yellow rice over the heads of people who intend to do something, or on the forehead, on the back of the hands and feet. Most people also sprinkle yellow rice around the place where the ceremony is perfomed. So is the ritual of giving strength (semongat) to the person who is prayed for while reciting the following prayer.

kuu... semongat

korin bosi korin semongat

panyang aik panyang penyawak

tinggi tayak tinggi tuah

baka tanah na tau susur

baka batu na tau pupur

Source: Uju Unui (alm), Interviewed in November 2009

This prayer is recited when the handing a piece of iron to be bitten by a person who is prayed for. Biting a piece of iron (mengecap besi ${ }^{\sigma}$ ) in the Malay tradition means giving strength or spirit to those who are prayed for to have the rigor of iron. In the tradition of the local communities, iron is a symbol of strength and spirit. This is the last series of the process of fresh flour prayer in the Malay community in Nanga Jajang. That is the meaning contained according to many sources in the field.

In addition, in the form above is still commonly found in some spells of traditional healing, and carries local content in nature, so that it seems difficult to understand the values contained in it. In other words, the possibility of the pattern is closer to the actual shape in old traditions (animism), before Islam came in the social history of the Malays. Here is an example of the lines of prayer intended as quoted from Hermansyah (2010), about pedora' spell.

\section{Perdora' spell:}

Mpurung sibang sibu

Ngelayang batang kepuas

Puki inai ikau bebulu

Butuh apang ikau pulas

Source: Hermansyah, 2010: 153

The lines of the prayer in the local language of the Malay community of Nanga Jajang not only had a clear sense, but it also illustrates one form of verbal abuse, humiliation and even tends to have obscene meaning (using taboo

6 The mengecap besi is done by biting a pice of iron in a smoot way. The point is that the teeth touch the iron as it is a symbol of ritual. 
words), especially in line 3 and 4 . Saying such words in social relationships of the Malays in Nanga Jajang is viewed as unethical and violates moral norms (social and religious norms as well). So, why is it used in the lines of a prayer and believed to be able to "cure" diseases? This is where the power of tradition and belief of the people who practice it in the form of suggestion. This is what tradition look like with all the values in the social and religious history of the Malay community in Nanga Jajang.

In other words, a strong belief that it has the power to cure in the traditional healing makes it still exist in society. Finally, it is a belief that actually brings the power of healing in the traditional treatment of disease. Meanwhile, the examples above indicate the accommodation of Islamic values in the traditional healing in Nanga Jajang village, both of which still have form magic and Islamic elements especially in the lines of the prayer recited. Such conditions can provide insight to some people that Islam and traditions are just the same. Meanwhile others can still see the differences between Islamic values and local traditions in some forms of prayer used in the traditional healing practiced in Malay society of Nanga Jajang.

\section{CLOSING REMARKS}

The above discussion indicates that the practice of cultural traditions is still common among the Muslim community in Nanga Jajang. Even in some parts, traditions that accompany religious practices (Worship) seem to resemble the worship itself. It seems that traditions are something that should exist in worship, as in the practice of ma 'asyiral in Friday prayer. In most of the parts, traditions practiced by the Muslim community in Nanga Jajang have already been influenced Islamic values in the form of the addition of the words bismillah, Allah and La Ila ha Illallah, Muhammadur rasulullah. The above discussion also proves that Islam came and was accepted by the people in Nanga Jajang who were very accommodating, maintaining the fine tradition while continuing to add the Islamic values in the all practices of the traditions. Finally, I hope that this simple review will be useful for all readers, Amen.

\section{REFERENCES}

Azyumardi Azra. 2002. Islam Nusantara: Jaringan Global \& Lokal. Bandung: Penerbit Mizan.

Barthon, Greg. 1999. Gagasan Islam Liberal di Indonesia. Jakarta: Paramadina. Erwin dan Andi Gidang. 2010. Tradisi yang membelajarkan: mengurai un- 
sur-unsur pendidikan dalam tradisi Tepung Tawar Melayu Sambas. Dalam Ibrahim (ed.) 2010. Tradisi dan Komunikasi Orang Melayu. Pontianak: STAIN Press. Hal 205-226.

Hermansyah. 2008. Islam Orang Embau. Yusriadi Yusriadi \& Ambaryani (Eds.). Islam dan Etnisitas di Kalimantan Barat. Pontianak: STAIN Press.

Hermansyah. 2010. Ilmu Ghaib di Kalimantan Barat, Jakarta: Kepustakaan Populer Gramedia.

King, Victor T. 1993. The People of Borneo, Oxford, Blackwell Publishers.

Ibrahim. 2010. Tradisi dan Komunikasi di Nanga Jajang. Dalam Ibrahim (ed.) Tradisi dan Komunikasi orang Melayu. Pontianak: STAIN Press.

Ibrahim. 2013. Kaum Nahdliyin: Antara Identitas Kultural, Ideologi Keagamaan \& Kepentingan Politik. Makalah untuk diskusi dosen tahun 2013, P3M STAIN Pontianak.

Ibrahim, Yusriadi \& Zaenuddin. 2009. Kearifan Komunikasi Pantang Larang pada Masyarakat Melayu Nanga Jajang. Laporan Penelitian Kompetitif. DIPA STAIN Pontianak.

Ibrahim, Yusriadi \& Zaenuddin. 2012. Pantang Larang Melayu Kalimantan Barat. Pontianak: STAIN Press. 